\title{
熱交換換気システムを用いた集合住宅の結露防止方法に 関する研究 \\ CONDENSATION FREE MULTIPLE DWELLING USING VENTILATION SYSTEM WITH HEAT EXCHANGER
}

\author{
福島 明*, 入江雄司** \\ Akira FUKUSHIMA and Yuji IRIE
}

\begin{abstract}
Concrete multiple dwelling seldom have serious condensation problem, because of lack of ventilation, partial heating system and inside thermal insulation. Condensation free method by using ventilation system with heat exchanger is presented in this paper. Experimental study on this system installed in the house suffered by serious condensation problem, shows that the system is successful and possible to avoid extreme dryness in heating area simultaneously. Minimum ventilation demand to avoid condensation problem and comparison with exhaust only system are discussed through calculation.
\end{abstract}

Keywords : condensation, multiple dwelling, ventilation system, heat exchanger 結露、集合住宅、換気システム、熱交換

\section{1.はじめに}

R.C.造集合住宅は、構造躯体の気密性が高く空や玄 関扉など開口部の気密性の向上によって、高い気密性を 実現している. ${ }^{1)}$ 。しかし、気密性の向上に伴うべき断熱 や換気、暖房の対応が不十分で、結露被害が後を絶たない 2)。北海道では、戸建て住宅には及ばないものの、外壁 や空の断熱性の向上によって、暖房室内での結露は減少 し、外付け押入や暖房のない北側の室などで生じる非暖 房室型結露が、主な結露障害となっている。寒冷地では、 冬期間外気の絶対湿度が低下するため、外断熱化など断 熱性を高め、全室暖房と適切な換気システムを取ること によって：結露障害を完全に防止することはそう困難な ことではない。しかし、こうした対応を一般的な集合住 宅に適応することは経済的に負担が大きく、内断熱で暖 房や換気の対応は、従来の部分間欠暖房と壁の換気レジ スター等による自然換気によっているのが現状である。 また、こうした集合住宅では、結露防止を居住者の住ま い方に負う部分が大きく、すでに建設された集合住宅で 結露被害を生じた場合、戸建て住宅とは異なり、断熱改 修や全室暖房の装備など、建築的な対応は容易亡゙ない。 断熱や空調設備の急速な普及を期待できない現状では、 既存住宅における結露防止対応を含めて、部分暖房を許
容しながら、既存の仕様のままで結露被害を防止する手 法が求められている。

集合住宅の結露被害とその対策については、多くの報 告がなされており、例えば池田らは、隅角部の結露のメ カニズムと吸放湿材の利用による結露障害の防止方法を 提案している ${ }^{3)}$ 。また、土屋は、集合住宅の温湿度の非 定常計算から、吸放湿や換気など総合的な結露防止対応 について検討している ${ }^{4)}$ 。しかし、いずれも結露を許容 しながら障害を回避する手法であり、寒冷な地域では生 活状態や温度の管理など僅かな対応の不備により、結露 障害を生じるリスクが高い。一方換気は、一般的な結露 防止対策の一つであり、寒冷地では壁掛型の熱交換換気 扇などが利用されている。しかし、熱交換によっても給 気温度の上昇は不十分で快適性を損なうことや、装置騒 音が直接室内に発生することなどから、部分的、一時的 な対策に限定されているのが害状である。

本研究では、熱交換型換気ジステムを用いて住宅内の 空気の流れを制御することにより、部分暖房の住宅でも 完全に結露を防止する手法を提案し、当該システムを設 置した既存住宅における実測により、その効果を明らか にした。また、住宅内の換気のシミュレーションにより、 空気の流れの制御に必要な換気量の検討、および集中排

* 北海道立寒地住宅都市研究所 工修

** 北海道立寒地住宅都市研究所
Hokkaido Prefectural Cold Region Housing and Urban Research Institute, M. Eng.

Hokkaido Prefectural Cold Region Housing, and Urban Research Institute 
気方式との性状比較を行った。

\section{2. 測定住宅と測定の概要}

\section{1 測定住宅の詳細}

測定した住宅の平面図を図 1 に示す。札幌市内に建つ R.C.造 2 階建て 6 戸入り集合住宅の 1 階西側端部住戸 である。1983 年建設で、築後 2 年間に南側居室の西向き の押入内部を始め、北側洋室の壁面全面などに著しい結 露とカビ被害が発生した。床面積約 $84 \mathrm{~m}^{2}$ で、居住者は 幼児一人を含む 3 人家族である。断熱は、38 mmの発泡ポ リスチレンをコンクリート同時打ち込みで施工しており、 隅角部は $10 \mathrm{~mm}$ の現場発泡ウレタンで断熱補強している。 開口部は空が、外側がペアガラス入りの防音型気密アル ミサッシ、内側が単板ガラス入り木建具で、ガラス 3 層 構造である。玄関にも断熱気密玄関ドアを採用しており、 換気口、換気設備を塞いで測定した相当隙間面積は、床 面積当たりで $1.8 \mathrm{~cm} 2 / \mathrm{m}^{2}$ であった。暖房は居間の F F 式 石油ストーブ 1 台による間久暖房で、強制換気装置は台 所と浴室、便所に設けられている。写真 1 は収納空間内 部のカビ被害状況である。

\section{2 換気システム}

換気システムの空気の流れの概念を図 2 に示す。結露 被害の顕著な押入内部や非暖房室に給気し、廊下や居室 を経由して、水蒸気の発生は最も多いが、暖房されてい て結露の恐れの少ない台所・居間空間から排気する。低 温空間から暖房空間への空気の流れを作ることによって、

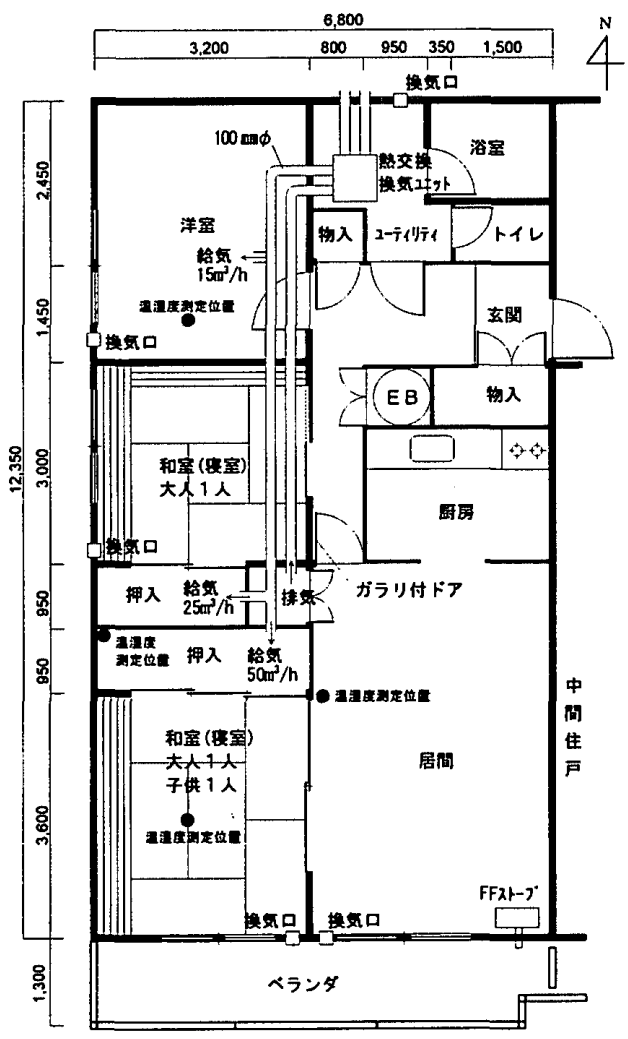

図 1 測定住宅の平面図(西側端部 $1 \mathrm{~F}$ )
温度の低い空間への水蒸気の移動を妨げ、湿度の上昇を 抑えるシステムである。

換気システムを図 1 中に示す。熱交換換気装置の本体 はユーティリティー天井面に吊り、各室への給排気には $100 \mathrm{~mm} \phi$ の塩化ビニール管を使用し、室内に露出配管し ている。水蒸気の排出が目的なので、熱交換換気装置に はM社製のクロスフロー型で顕熱回収タイプの装置を使 用しており、装置内部の結露水を排出するためドレーン を設けているほか、ウレタンシートにより本体の防露対 策もされている。給気口は南側および西側の和室押入内 部と北側洋室に設け、排気は居間の収納空間から行った。

押入内への給気は、熱回収によっても加温の不十分な 取り入れ外気を更に室温に近づける効果が期待され、押 入内の乾燥化と同時に、外気の導入による居住空間の環 境覀化を防ぐ上で大きな効果が期待できる。

\section{3 測定の概要}

換気装置は、1987 年の暖房開始前に設置し、換気装置 の運転状況は、実験期間中を除いて弱ノッチで連続運転 である。水蒸気発生に関わる居住者の生活に関して、特 別な制約は $\phi$ く行っていない。給気口に約 $30 \mathrm{~cm}$ の円筒 を取り付け、中心風速を熱線式微風速計で計測すること により各給気口の給気風量を推定した結果、弱ノッチで 南側和室押入、西側和室押入、北側洋室それぞれ約 50 、 25、 $15 \mathrm{~m}^{3} / \mathrm{h}$ であった。室内への給気口は風量調節ので きないガラリタイプが設置されており、給気量に差を生 じているが、実測はこの風量のまま実施した。

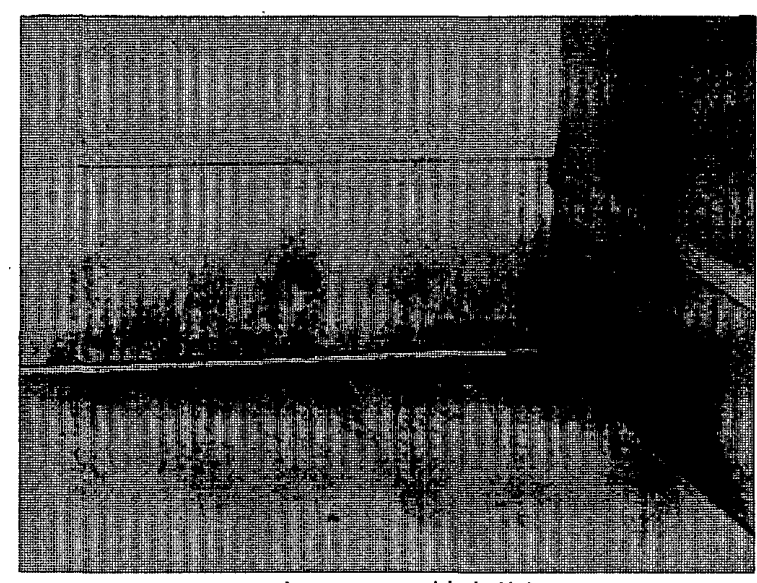

写真 1 カビ被害状況

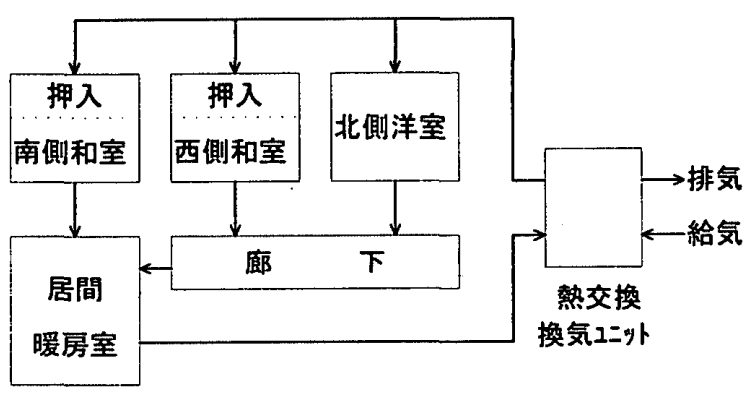

図 2 熱交換換気システムの概念図 


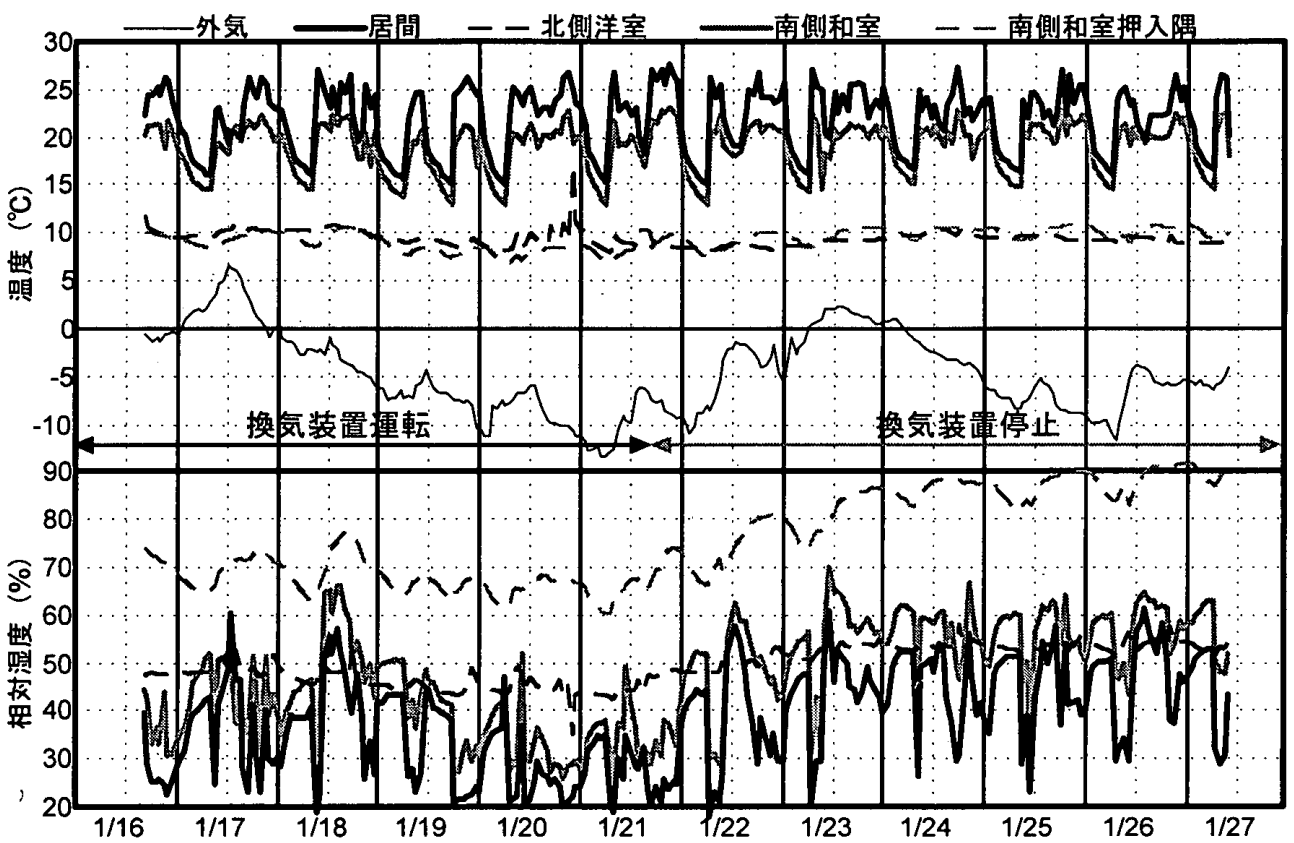

図 3 換気装置運転時と停止時の各部温湿度変動

外気温度の最も低下する 1 月下旬に、換気装置の連続 運転を継続しながら 1 週間測定し、その後換気装置を停 止して 1 週間の測定を実施した。温湿度の測定個所は図 1 中に示すとおりである。測定機器には、S 社製の電気 抵抗式温湿度センサーを使用した。押入内部の隅の測定 は、衣類の入った段ボール箱と外壁側壁面の僅かな隙間 を利用し、センサーを奧の隅角部床面に㯰いた。その他 の空間の温湿度は全て、床上 $1.8 \mathrm{~m}$ で測定している。

\section{3. 測定結果と考察}

\section{1 温湿度の日変動}

図 3 は、测定期間中の住宅内各部の温湿度変動を示し たものである。換気装置運転時には、外空のアルミサッ シ面に僅かな水滴が見られる他は全く結露は発生してい ない。換気装置停止後、居間の相対湿度が僅かの時間で 上昇し、続いて押入内部の隅をはじめ北側洋室など、非 暖房空間の湿度が徐々に上昇する。換気装置停止後 3 日 目にはある程度安定し、相対湿度が $90 \%$ に達する部分も 出現する。結露現象としては、換気装置を停止した翌日 には暖房空間の外側アルミサッシの面に、2 日後には、 北側洋室の 3 重ガラスの室内側表面に流れ落ちるほどの 結露を観測している。また、3日目には、北側洋室の床 プラスチック幅木面にも水滴が確認された。前年まで結 露被害の大きかった押入内隅角部については、測定完了 後に目視で調査したが、結露の被害が発生した様子は見 られなかった。ガラス面やプラスチック面など吸湿性の ない素材面では湿度の上昇に伴ってすぐに現象となって 現れるが、押入内部など吸湿性のある部分では、結露被 害の発生までには時間を要することがわかる。
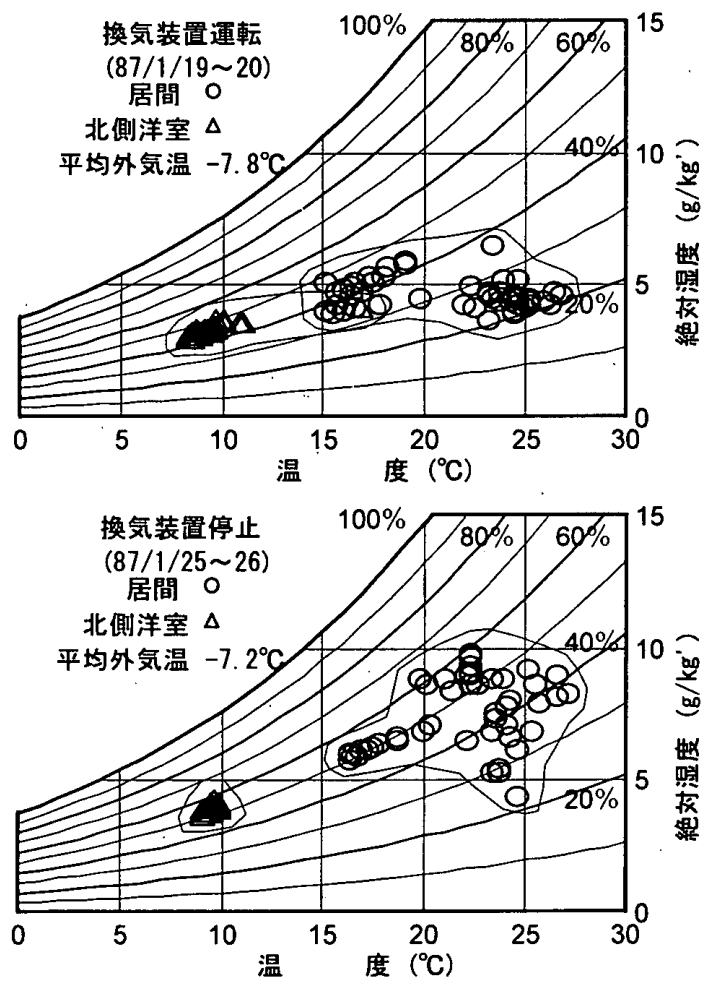

図 4 換気装置の運転・停止時の温湿度

3.2 換気装置運転時と停止時の温湿度比較

換気装置の運転期間中と、停止後ある程度湿度が安定 した期間それぞれ 2 日間の温湿度を湿り空気線図上にプ ロットし、換気装置の運転による影響を検討した。図 4 は、居間及び北側洋室の温湿度を比較したものである。 換気装置の運転時には、居間の絶対湿度は $5 \mathrm{~g} / \mathrm{kg}$ 前後で 一定しており、室温が $25^{\circ} \mathrm{C} に$ 達する暖房時間帯には相対 


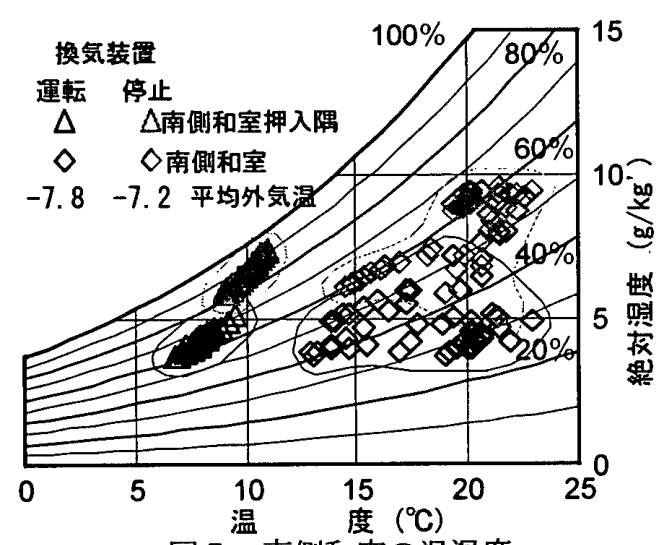

図 5 南側和室の温湿度

湿度が $25 \%$ 程度まで低下している。外気の給気 側になる北側洋室では、それより $1.5 \mathrm{~g} / \mathrm{kg}$ 程度 低く保たれ、相対湿度も約 $45 \%$ で安定している。 これに対して、換気装置停止時（停止 4 日後） には、絶対湿度が暖房時間带に高く、暖房停止 表 1 各部の通気特性

\begin{tabular}{|c|c|c|}
\hline 部位 & $\begin{array}{c}\text { 通気率 } \\
\mathrm{m}^{3 / \mathrm{h}} \cdot \mathbf{m m A q} \mathbf{A q}^{1 / \mathrm{n}}\end{array}$ & $\mathrm{n}$ 值 \\
\hline ふすま（押入、和室） ${ }^{*}$ & $52\left(\mathrm{~m}^{2}\right.$ 当たり) & 1.5 \\
\hline ドア (北側室、居間) ${ }^{*}$ & $14\left(\mathrm{~m}^{2}\right.$ 当たり $)$ & 1.5 \\
\hline 換気口（丸形自然給気口） ${ }^{* *}$ & 20 (1 ヶ所当たり) & 1.5 \\
\hline 換気口以外の隙間*** & 216 (全体) & 1.5 \\
\hline
\end{tabular}

表 2 水蒸気発生量 9)、10)

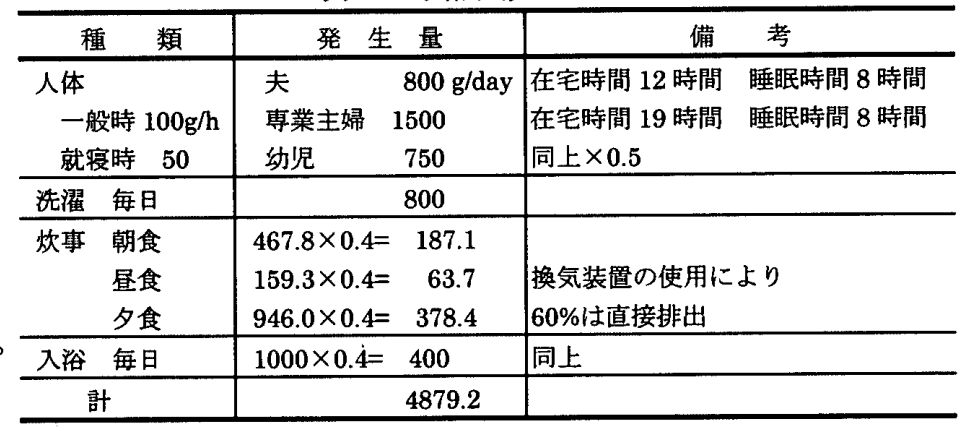

時には低い傾向が見られ、むしろ相対湿度が $50 \%$ 前後で 安定している。これは、暖房停止時には、空面での結露 などで絶対湿度が低下するためと考えられる。北側洋室 は、換気装置運転時に比べて僅かに相対湿度が上昇する が、暖房空間ほど大きな変化ではない。温度については、 換気装置の運転による影響はほとんど見られない。

図 5 は、南側居室と付属する押入内部隅角部の温湿度 を、換気装置の運転時と停止時について示したものであ る。換気装置の停止によって押入内隅角部の相対湿度は、 平均 $66 \%$ から $87 \%$ に上昇し、換気装置運転時には $70 \%$ を越えないのに対して、換気装置停止後は長時間 $90 \%$ を 越える。換気量の增大によって室内の絶対湿度自体が低 くなっていることを考虑しても、換気装置の運転による 低温部分の結露防止効果は顕著である。温度は、給気量 が $50 \mathrm{~m}^{3} \mathrm{~h}$ と多いこともあり、換気装置の運転時の方が $2{ }^{\circ} \mathrm{C}$ 程度低く推移する。熱交換により温度が上昇してい るとはいえ、室内への直接給気は温度環境に影響するも のと考えられる。当該システムは、風量調節によって室 間に絶対湿度の差を作りながら、非暖房室の結露と暖房 室の過度の乾燥を同時に防ぐことが可能で、こうした特 性を生かす上でも非暖房空間の結露防止に必要な給気量 を把握し、適切に調整することが必要と考えられる。

\section{4.換気と湿度性状の定常計算による検討}

本研究で提案する結露防止法は、非暖房室から暖房空 間への空気の流れを作り、非暖房室への湿気の流れを減 少させる手法である。これによって、暖房室の湿度を過 度に低下させることなく、非暖房空間の結露を防ぐこと ができる。換気装置の運転が住宅内の空気の流れと各室 の絶対湿度に及ぼす影響を明らかにする事を目的に定常 計算を行った。吸放湿を考慮した防露設計には非定常計
算が必要であるが、換気経路の設計によって結露を完全 に防止することを目的とする本研究では、定常計算によ る検討で特性を検討することが可能と考えた。

\section{1 計算方法と条件}

換気の計算は、各室の風量収支式を圧力仮定の Newton-Raphson 法による近似計算で解くことにより 行った。収束計算の補正值に対する緩和係数として 0.6 を用いた ${ }^{6)}$ 。風量收支は物質収支なので重量風量で計算 した。計算に用いた通気各部の特性を表 1 に示す。主要 な室内建具および換気口の通気特性は、土屋 7、石原 8) の値を用い、建物の換気口以外の隙間の通気特性は、減 圧法によって求めた実測値である。各通気部位の隙間は、 その上下端高さの位置に集中しているものとし、部位全 体の通気率を 2 等分して配目した。換気口以外の隙間は、 各室の空の上下端高さの位置に集中しているものとし、 全体の通気率から各室の床面積で按分して求めた各室の 通気率を、2等分してそれぞれの高さの位置に配置した。 換気装置運転時の排気量は給気量と同一とした。

絶対湿度は、各室で水分収支により計算した。ふすま 部位のみ透湿を考慮した。 ${ }^{\text {泩 }}$ 水蒸気の発生量は表 2 に示 すように設定し、1 日の発生量 $4.8 \lambda$ を時間平均し、 $200 \mathrm{~g} / \mathrm{h}$ とした。水蒸気の発生モードとして、次の 2 種類 を設定した。

モード 1 : 寝室に使われている南和室および西和室でそ れぞれ $20 \mathrm{~g} / \mathrm{h}$ 、北側洋室とユーティリティー でそれぞれ $15 \mathrm{~g} / \mathrm{h} 、 130 \mathrm{~g} / \mathrm{h}$ が居間で発生する。 モード 2 : 就寝時を想定して、主寝室の南側和室で $75 \mathrm{~g} / \mathrm{h}$ 、 西側和室で $50 \mathrm{~g} / \mathrm{h} 、 75 \mathrm{~g} / \mathrm{h}$ が居間で発生する。

温度条件は比較的外気条件が安定した 1 月 19、20日 の 48 時間平均值を使用し、外気の相対湿度は $90 \%$ とし た。風量収支式及び水分収支式を注 2 に示す。 

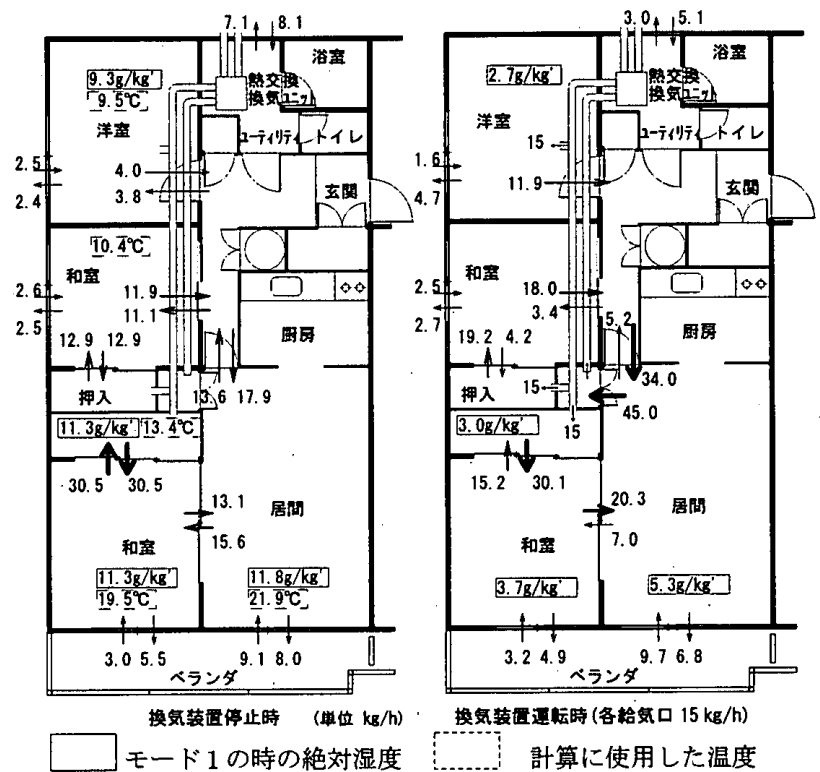

図 6 換気量・絶対湿度のシミュレーション結果

表 3 各室の絶対湿度計算結果 $\quad(\mathrm{g} / \mathrm{kg})$

\begin{tabular}{c|c|c|c}
\hline \multirow{2}{*}{} & 水蒸気発生 & \multicolumn{2}{|c}{ 換気装置 } \\
\cline { 3 - 4 } & モード & 停止時 & 運転時 \\
\hline 北側洋室 & モード 1 & 9.29 & 2.73 \\
\cline { 2 - 4 }$(7.31)$ & モード2 & 6.56 & 1.83 \\
\hline 押入内隅 & モード1 & 11.32 & 3.01 \\
\cline { 2 - 4 }$(6.69)$ & モード 2 & 13.52 & 4.45 \\
\hline 南側和室 & モード 1 & 11.32 & 3.71 \\
\cline { 2 - 4 }$(12.91)$ & モード2 & 13.52 & 6.00 \\
\hline
\end{tabular}

( ): 各空間の空気温度による飽和絶対湿度 $\left(\mathrm{g} / \mathrm{kg}^{\prime}\right)$

\section{2 計算結果と考察}

(1)住宅内の空気の流れと絶対湿度

図 6 は、換気装置運転時と停止時の各部の空気の流れ である。換気装置停止時には換気量は全体で約 $22 \mathrm{~kg} / \mathrm{h}$ 、 換気回数約 0.1 回/hである。外部風を考慮に入れていな い計算であるが、衛生上の必要換気量を満たしていると はいえない状況である。また、表 3 は各室内の絶対湿度 の計算結果であるが、換気装置停止時には、北側洋室や 押入内隅など温度の低い空間ばかりでなく暖房空間でも 飽和絶対湿度を上回り、住宅全体が結露条件となる。室
間の空気の流れを見ると交換換気による暖房空間から非 暖房空間への空気の流れが見られ、北側洋室で室内の水 蒸気発生のないモード 2 の条件でも絶対湿度が上昇し結 露条件に至っている。

換気装置運転時の計算結果は、各給気口から $15 \mathrm{~kg} / \mathrm{h}$ 供給され、その合計量を居間から排気するとして計算し た結果である。この結果、全体換気量は $67 \mathrm{~kg} / \mathrm{h} 、 0.3$ 回 $\mathrm{h}$ に増大し、 3 人家族で、平均在宅人数を 1.5 人とする と、ほぼ必要換気量を満たしているといえる。1 室当た りの給気量としてはごく僅かであるが、いずれの条件で も低温部分の温度から計算した飽和絶対湿度を下回り、 結露の可能性は全くない。寝室の発生量を增加した設定 では、寝室内の絶対湿度が上昇し、相対湿度で約 $45 \%$ と なっているが、結露の発生には至らない。空気の流れを 見ると、非暖房室から暖房室への明確な流れが生じ、暖 房室から非暖房室への流れが極端に低下し、意図した空 気の流れが生じている。

(2)非暖房室における就寝時の必要給気量

図 7 は給気量の変化と各空間の絶対湿度である。日中 を想定したモード1では、各給気口の給気量を $10 \mathrm{~kg} / \mathrm{h}$ 、 水蒸気の発生を寝室中心にしたモード 2 でも $15 \mathrm{~kg} / \mathrm{h}$ の 給気量を確保すると、いずれの空間でも飽和に達するこ とはない。換気装置の換気能力は、弱運転時定格出力 41 W、 $88 \mathrm{~m}^{3} / \mathrm{h}$ であるが、ダクト亲の抵抗により実質約 60 $\mathrm{m}^{3} / \mathrm{h}(76 \mathrm{~kg} / \mathrm{h})$ 程度期待できる。このことから、こうし た小型の熱交換換気装置により、住宅内に空気の流れを 作り、結露をほぼ完全に防止することが可能で、その必 要な給気量は、全体で $45 \mathrm{~kg} / \mathrm{h}$ 程度である。

(3)ユーティリティーにおける強制排気方式の比較

住宅内に空気の流れを作る簡便な手法として、ユーテ ィリティーの既存排気ファンを利用する方法がある。そ こで、本研究で提案する熱交換換気システムによる方法 との比較を試みた。全体換気量をパラメーターとし、水 蒸気発生量をモード 2 として各室の絶対湿度および相対 湿度を計算した結果を図 $8 、 9$ に示す。熱交換換気シス テムの場合は各給気口に均等に給気するものとした。

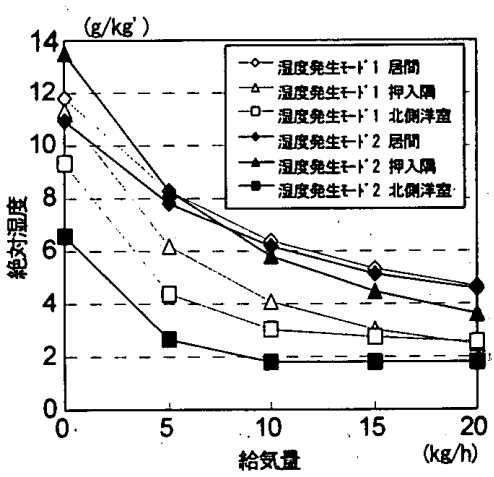

図 7 給気量の変化による絶対湿度

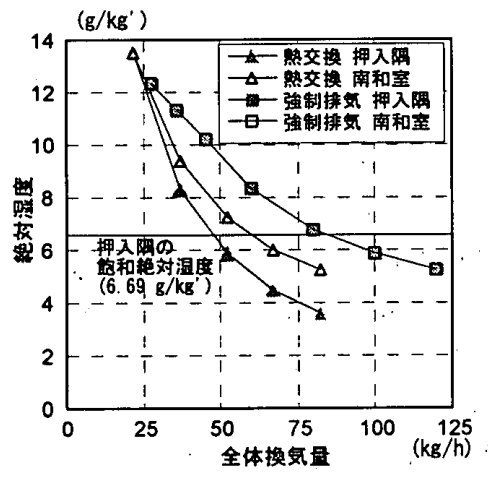

図 8 換気方式による絶対湿度の比較

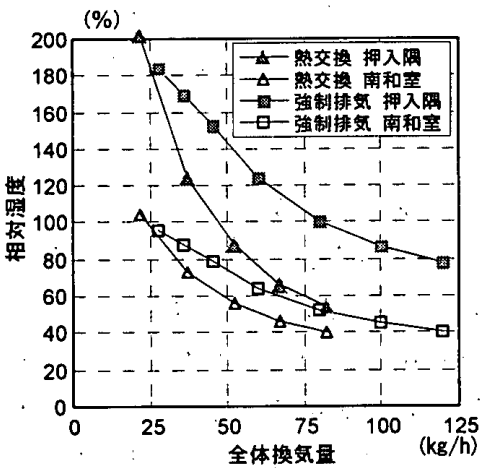

図 9 換気方式による相対湿度の比較 
押入隅の絶対湿度が、飽和絶対湿度を下回る時の全体 換気量は、熱交換換気システムの 約 $45 \mathrm{~kg} / \mathrm{h}$ に対して、 強制排気方式では、 $80 \mathrm{~kg} / \mathrm{h}$ と大きな差を生じる。また、 熱交換換気システムでは、給気量 $45 \mathrm{~kg} / \mathrm{h}$ 、総換気量 $67 \mathrm{~kg} / \mathrm{h}$ 程度の換気量で、押入隅の相対湿度は $60 \%$ 以下 に低下する。これに対して、強制排気方式では、室内と 同じ絶対湿度になるため、総換気量を $120 \mathrm{~kg} / \mathrm{h}$ にしても、 押入隅の相対湿度は $80 \%$ 程度にしかならない。熱交換換 気方式では、押入内給気によって、押入内部が居室より 絶対湿度が低く保たれ、押入内隅の相対湿度が $60 \%$ でも、 居室の相対湿度は 40\%を維持できる。強制排気方式で押 入内隅の相対湿度を同様に低湿に維持寸るには、さらに 多くの換気を必要とし、室内の低湿化が避けられない。 いくら換気量を増しても、乾燥感から加湿を行えば、結 露の危険性は容易に高まることになる。こうした各空間 の湿度管理の点からも、本研究で提案した方式の利点は 少なくない。

\section{5.まとめ}

気密性に優れた部分暖房の集合住宅を対象に、熱交換 換気システムによる結露防止方法を提案し、実測とシミ ュレーションにより、その効果と特性を明らかにした。 (1)既存住宅の実測から

結露とカビの被害を発生した既存の集合住宅で、当該 システムを設置したことにより結露障害は完全に解消し、 結露防止に大きな効果を得た。換気装置の運転時と停止 時の、室内各部の温湿度環境を測定した結果、換気装置 の停止によって、短時間に相対湿度が上昇し、 $2 ， 3$ 日 で各部に結露を生じた。また、結露被害の著しかった押 入の隅では表面結露は確認できなかったが、相対湿度が $70 \%$ から 90\%に上昇し、著しい高湿化が観測された。 (2)換気と湿度のシミュレーションから

換気経路と結露の防止に必要な給気量の検討を目的に 換気と湿度に関する定常計算を行った結果、 $45 \mathrm{~kg} / \mathrm{h}$ 程度 の給気量で、住宅内に有効な空気の流れを生じさせ、結 露を完全に防ぐことが可能なことが明らかとなった。ま た、ユーティリティーのファンを利用した強制排気シス テムとの比較した結果、強制排気システムでは、同じ効 果を得るために 2 倍程度の換気量が必要なこと、このこ とによって、居室の相対湿度が低下寸ることが明らかに なった。

寒冷地では、換気自体が寒さの原因となり、積極的な 換気がおろそかになりがちである。気密化の普及と共に 被害の様相が変化し、カビやダニによる健康被害が心配 される中で、室内の温度環境を損なうことなく、基本的 な換気量を確保できることから、熱交換換気システムに よる換気は、集合住宅の環境改善に大きな効果が期待で きると考えられる。
謝辞：熱交換換気方式の利用に関して、北海道大学荒谷 教授から、貴重な助言を頂きました。記して感謝します。

参考文献

1)村上周三，矢作和久，長谷川攻，大山信一：集合住宅の気密性能 と換気設備の実測調查（その1），日本建築学会大会学術䠄演梗 概集, 1984.10 .

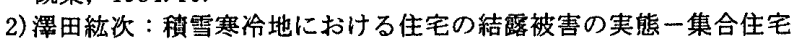
における実態調查の結果からー, 日本建築学会熱環境委員会, 第 21 回熱シンポジウム, pp169〜177, 1991.8.

3) 池田哲郎：結露のある場合の室内温湿度变動（一戸建て住宅にお ける結露性状と吸放湿材貼付効果), 日本建策学会熱環境委員会, 第 21 回熱シンポジウム, pp85〜94, 1991. 8.

4) 土屋喬雄：住宅の結露防止性能評価法（その 4 ）, 日本建築学会 大会学術䛾演梗概集, pp743 744, 1981. 10.

5) 土屋喬雄：住宅の結露防止性能評価法（その5)，日本建築学会 大会学術䛾演梗概集, pp791 792, 1982. 10.

6)石田建一，宇田川光弘：換気及び室相互のふく射を考慮した多数 室室温・熱負荷計算法，日本建築学会論文報告集第 381 号, pp46 $\sim 55,1987.11$

7) 土屋喬雄：住宅の結露防止性能評価法（その3），日本建築学会 大会学術講演梗概集, pp615 616, 1980. 10.

8) 建築換気設計, 石原正雄著，朝倉書店

9)建案設計资料集成 1 環境，日本建築学会編，丸善株式会社

10)最新建築謤境工学, 土屋喬雄他著, 井上畫院

関連論文

I )福島明，入江雄司，川治正則：R.C. 集合住宅の換気対策による㻴 境改善効果, 日本建築学会大会学術講演梗概集, 1987. 10.

II ) 福島明, 入江雄司：R.C. 集合住宅における室内の部分環境の実体、 日本建築学会大会学術隣演梗概集, 1988. 10.

注 1

ふすまの湿気望流率 $\left[0.61\left(\mathrm{~g} / \mathrm{m}^{2} \cdot \mathrm{h} \cdot\left(\mathrm{g} / \mathrm{kg}^{\prime}\right)\right)\right]$ は、温度 $20^{\circ} \mathrm{C} 、$ 断面構造を $2.7 \mathrm{~mm}$ ベニヤ $+20 \mathrm{~mm}$ 空気層 +2.7 四四べニヤとして、参考文献 9 より算 出した。

注 2

換気計算に用いた収支式は以下のとおりである。

換気収支式

$\sum_{j=1}^{N_{i}} Q_{i j}=0$

$Q_{i j}=\sum_{k=1}^{M_{i j}}\left(A_{i j k} \times \gamma_{j} \times \Delta P_{i j}^{1 / n}\right)$

水分収支式

$\sum_{j=1}^{N_{i}}\left(Q_{i j}+K_{i j}\right) \times\left(X_{j}-X_{i}\right)=0 \ldots \ldots$

記号

$N_{i}: \mathrm{i}$ 室と通気する室数

$M_{i j}: \mathrm{i}$ 室と $\mathrm{j}$ 室の通気部位数

$Q_{i j}: \mathrm{i}$ 室から $\mathrm{j}$ 室への通気最 $(\mathrm{kg} / \mathrm{h})$

$A_{i j \mathrm{k}}: \mathrm{k}$ 番目の部位の通気率 $\left(\mathrm{m}^{3} / \mathrm{h} \cdot \mathrm{mm} \mathrm{Aq}^{1 / \mathrm{h}}\right)$

$\gamma_{j}: \mathrm{j}$ 室の空気密度 $\left(\mathrm{kg} / \mathrm{m}^{3}\right)$

$\Delta P_{j j k}: k$ 番目の通気部位の両側の圧力差 $(\mathrm{m} \mathrm{m} \mathrm{Aq})$

$\mathrm{n}$ : 通気特性值 $(1 \sim 2)$

$K_{i j}: \mathrm{i}$ 室と $\mathrm{j}$ 室の間の湿気貫流率 $\left(\mathrm{g} / \mathrm{h} \cdot\left(\mathrm{g} / \mathrm{kg}^{\prime}\right)\right)$

$X_{i}, X_{j}: \mathrm{i}$ 室、 $\mathrm{j}$ 室の絶対湿度 $\left(\mathrm{g} / \mathrm{kg}^{\prime}\right)$

（1995年 7 月 6 日原稿受理，1995年11月 9 日採用決定） 